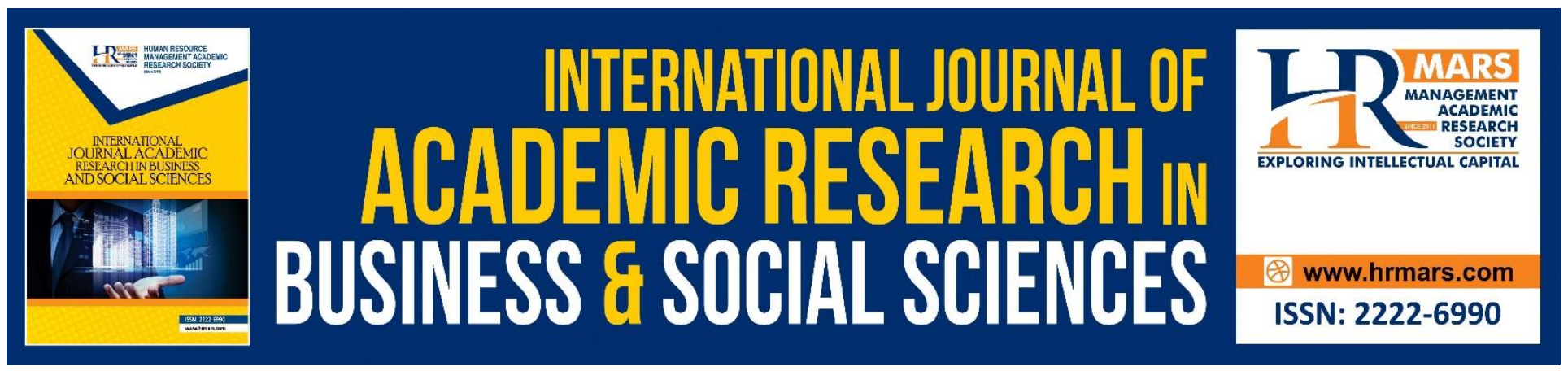

\title{
Ibn Khaldun's Theory of Good Governance in Achieving Civilization Excellence
}

Suhaila Abdullah

To Link this Article: http://dx.doi.org/10.6007/IJARBSS/v8-i9/4699

DOI: $\quad 10.6007 /$ IJARBSS/v8-i9/4699

Received: 11 August 2018, Revised: 04 Sept 2018, Accepted: 29 Sept 2018

Published Online: 15 October 2018

In-Text Citation: (Abdullah, 2018)

To Cite this Article: Abdullah, S. (2018). Ibn Khaldun's Theory of Good Governance in Achieving Civilization Excellence. International Journal of Academic Research in Business and Social Sciences, 8(9), 1321-1333.

Copyright: (C) 2018 The Author(s)

Published by Human Resource Management Academic Research Society (www.hrmars.com)

This article is published under the Creative Commons Attribution (CC BY 4.0) license. Anyone may reproduce, distribute, translate and create derivative works of this article (for both commercial and non-commercial purposes), subject to full attribution to the original publication and authors. The full terms of this license may be seen at: http://creativecommons.org/licences/by/4.0/legalcode

Vol. 8, No. 9, September 2018, Pg. 1321 - 1333

http://hrmars.com/index.php/pages/detail/IJARBSS

JOURNAL HOMEPAGE

Full Terms \& Conditions of access and use can be found at http://hrmars.com/index.php/pages/detail/publication-ethics 


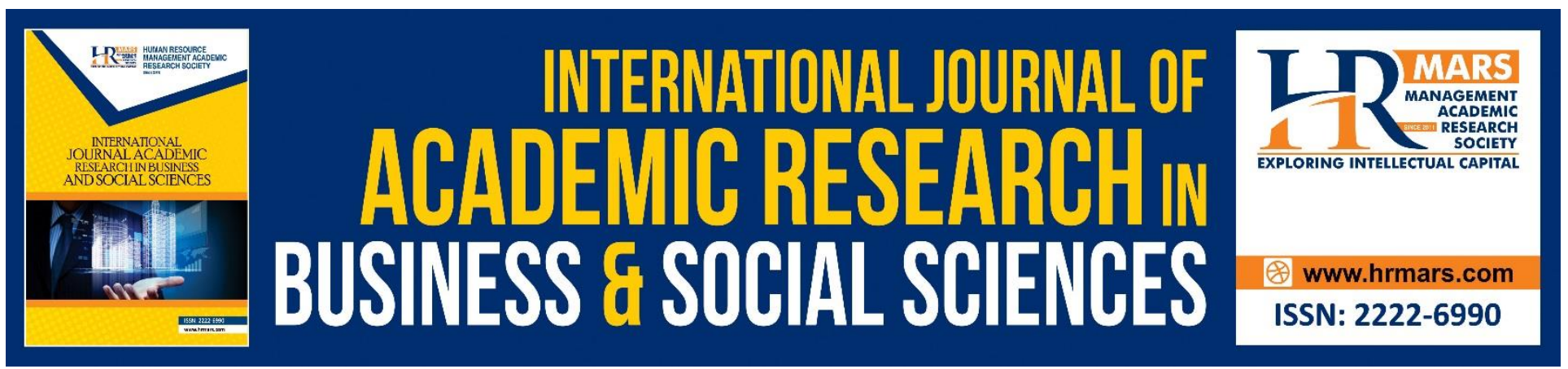

\title{
Ibn Khaldun's Theory of Good Governance in Achieving Civilization Excellence
}

\author{
Suhaila Abdullah \\ School of Humanities, Universiti Sains Malaysia, Penang, Malaysia
}

\begin{abstract}
Ibn Khaldun was the most prominent medieval Muslim scholar famed for his theory and philosophy of history and insights into the rise and fall of civilizations. This article attempts to discuss Ibn Khaldun's theory of good governance based on his monumental work, al-Muqaddimah. Although there is a great deal of scholarship that has been dedicated to the interpretation of Ibn Khaldun's political theory contained in the Muqaddimah, there are still a limited number of works that deal exclusively with his concept good governance and characteristic of good leader to ensure prosperity of the state. Hence, through the use of qualitative content analysis on Muqaddimah text, this article explores Ibn Khaldun's theory of good governance. This article opines that Ibn Khaldun was a genius Muslim figure who has lots of experience in politics and government that he has successfully translated them into his writing as reference for others. Obviously, there are undoubtedly direct connections between good governance, good leadership, economic prosperity and civilization excellence. In one way or another, as a Muslim who conducted studies pertaining to civilization, politic and human society, Ibn Khaldun himself could not escape from touching the instrumental aspects of religions from being discussed. In his theory, Ibn Khaldun always highlighted suggestions and solutions based upon his Islamic worldviews. Thus, Ibn Khaldun's theory of good governance and characteristic of good leaders are laid upon a solid religious foundation that is rational and acceptable to the mind.
\end{abstract}

Keywords: Ibn Khaldun, Al-Muqaddimah, Good Governance, Civilization, Leadership

\section{Introduction}

Good governance and characteristic of good leadership are arguably virtually essential to sustain effective administration of a state and at a broader level, an excellent civilization. Despite the proliferation of the good governance concept in the broader academic literature, there is little agreement on definitions, scope and what actually constitutes good governance. This is arguably due to the fact that empirical research on the topic, with some exceptions, is generally limited to case studies without use of any common conceptual framework. For instance, there are many theories of good governance models developed by North (1990), Olson (2000), Bates (2001) and Khan (2007) 
and Mohammad (2010) which focus on the economic aspect whereas Graham, Amos \& Plumptre (2003), Agere (2000) and Mohamed (1998) discussed the theory of good governance in terms of state administration.

Essentially, governance refers to the exercise of political as well as administrative authority at various levels to manage a country's affairs (UN system task team on the post-2015 UN development agenda 2012, p.3). Besides, governance also allude to a combination of ideas pertaining to political authority, management of economics and social resource and the capability of the government to formulate sound policies and perform their functions effectively, efficiently and equitably (Blunt 1995).

The term of 'good governance' has been deliberated in the development discussion by a World Bank study, which focused on the role of the state in the development process (Maldonado 2010). Good governance usually refers to type of government, and its political values and also certain other additional components (Smith 2007). World Bank (1992) defines good governance as "the manner in which power is exercised in the management of a country's social economic resources for development" (p. 1). Apart from that, good governance also includes the legal system, health and education, as well as culture, of which had enumerated under religion, civilization, and state prosperity (Wagener 2004).

On the other hand, good governance and leadership can be defined as the process of influencing others to facilitate the attainment of organizational relevant goals. This definition is applicable to both formal and informal leadership position in order to exert leadership behavior (Ivancevich, Konopaske \& Matteson 2008; Joseph, David, Kikelomo 2016). Meanwhile, Mohamed (1998) defined good governance as 'the exercise of political, economic and administrative authority to manage a nation's affairs' (p. 441).

In essence, birth and the formation of a human civilization cannot be separated from the existence of a wise leader who is responsible for governing and ruling the state. Due to the importance of this matter, a renowned scholar in the field of civilization known as Ibn Khaldun, or his real name, Abu Zayd Abd al-Rahman Ibn Muhammad Ibn Khaldun al-Wali al-Din al-Hadrami Tunisi alIshbili al-Maliki (1332 -1406M) had discussed about good governance in his book entitled alMuqaddimah written in $14^{\text {th }}$ century. In this masterpiece, he wrote based upon his experience, observations, and his research related to the construction, consolidation and fall of a human civilization. Hence, Ibn Khaldun is well known as the founder of the sociology of knowledge or knowledge of al-umran (civilization) as termed by him in his Muqaddimah.

\section{Background of Ibn Khaldun's Work}

Ibn Khaldun is regarded to be one of the brightest and most brilliant minds of Muslim world. He had contributed ideas and theory to many fields of knowledge. His full name is al-'Allamah Wali al-Din Abu Zayd 'Abd al-Rahman Ibn Muhammad Ibn Khaldun and was a famous historian and Muslim thinker of the $14^{\text {th }}$ century. He is considered as the founder of the science of human society as well as the forerunner of the original theories in social science, philosophy of history and economics (Campo 2009). He has been described as the first Muslim scholar to write about the science of umran (urbanism). In his book entitled al-Muqaddimah (an Introduction) Ibn Khaldun wrote significant 
opinions about good governance which were fully explained throughout several chapters of alMuqaddimah.

According to Ibn Khaldun in his Kitab al-lbar, he had stated that he himself was involved in politics and government for quite a significant period of time. Therefore he was able to write and carefully scrutinize the theory of good governance in depth in his writing. Ibn Khaldun begins his political career since he was 20 years of age. He was invited by Muhammad Ibn Tafrakin for an appointment as a royal secretary to Sultan Abu Ishaq, at the government of Tunisia in $1352 \mathrm{M} / 751 \mathrm{H}$ (Enan 1979). In short, Ibn Khaldun has been involved in politics and administration for approximately 20 years. As such, he is eligible, knowledgeable and has wide experience to discuss about the theory of good governance that can be emulated and benefited by the later society.

Ibn Khaldun asserted that human beings were created as political or social being in nature as they always need one another to sustain life. Hence human beings need to live in a community or society with mutual cooperation. Ibn Khaldun observed that human cooperation and social organization are necessities (dharury) for a civilization to evolve (Ibn Khaldun, 2000). For example in order to fulfil human's need for food, it needs a lot of efforts and process starting from planting the seeds and harvesting the grains among farmers and utensils create by the carpenters or blacksmith to create a machine to grind the wheat and only then people can use the flour to prepare the breads.

Besides the need for food human beings also require helps in defense against threat or danger. Therefore the need to appoint someone who has the authority and control is then increased. The appointment of a leader as well as his assistants portrays how the formation of a reign (al-daulah) started to be established.

\section{Theory of the Establishment of Human Civilization}

There are many theories about the history of human civilization. Among the famous theories are from Sigmund Freud (1856-1939), Charles Darwin (1809-1882) and Immanuel Kant (1724-1804). Freud in his conjectural psycho-analyses theory suggested that civilization depends on the repudiation of instinctual gratification and mastery over animal instincts, where the need for sexual gratification appears before their need for food or shelter (Freud 2005).

Meanwhile, Charles Darwin believe in his theory of evolution where he wrote that "The early forebears of man were ... probably furnished with great canine teeth but as they gradually acquired the habit of using stones, clubs or other weapons for fighting with their enemies of their rivals, they would use their jaws and teeth less and less. In this case, the jaws together with the teeth would become reduce in size" (Darwin 1981 p. 126-128 and as quoted by al-Ahsan \& Young 2017 and Leakey 1995).

In the meantime, Kant (1963) suggested the beginning of human history on the basis of the teachings of the Old Testament whereby he had focused on the lessons that can be learned from the biblical version pertaining to the beginning of man and the fact that man is taught that he must not blame his misfortune on Providence as well as he must not attribute his offence to the original sin.

Four centuries before Kant (1724-1804) Charles Darwin (1809-1882) and Sigmund Freud (18561939), a Muslim thinker known as Ibn Khaldun (1332-1406) had already adopted a rational but believer's approach in observing civilization and societal change. Ibn Khaldun's theory of administration is basically based upon Islamic principles which are comprehensive as they 
incorporate both moral and spiritual dimensions. Ibn Khaldun opined that a civilized human life begins with the establishment and growth of a city, resulting in the formation administrative system, development of economic system, production, technologies, culture, arts and so forth. Social solidarity is the result of asabiyyah spirit or sense of belonging in society (Ibn Khaldun 2000).

Ibn Khaldun viewed that the basic human needs can be divided into two basic needs such as need for food as the preservation of self and of human life and secondly is the need for self-defense so as to protect people from any threat. Therefore, to fulfill these requirements, there is a need for social contact between people to help and cooperate with each other, especially in the production of crops, food supplies and also in defense. Quranic verses as quoted in Ibn Khaldun's Muqaddimah are extremely clear on this matter:

"And Allah has extracted you from the wombs of your mothers not knowing a thing, and He made for you hearing and vision and intellect (heart) that perhaps you would be grateful." (al-Quran 16:78)

\section{Good Governance According to Ibn Khaldun's Theory}

Essentially, Ibn Khaldun (2000) explained that civilization secured cooperation among people and their participation in the socio-cultural-political process which are carried out through ethical and good moral conduct. Ibn Khaldun affirmed that civilization cannot be achieved through coercion instead it had to be attained through cooperation among human beings. Hence certain values need to be inculcated in the individual self and spread it in everyone's heart.

Generally, Ibn Khaldun believed that good governance is part and parcel of every civilization. Civilization requires a set of rules and regulations to ensure a harmonious and orderly society. The purpose of rules and regulations are to govern and regulate human actions. Hence, in his theory of good governance, Ibn Khaldun had suggested the importance of asabiyyah which denotes group solidarity and sense of belonging. In this regard, Ibn Khaldun affirmed that strong asbiyyah indicates good character and high qualifications of leadership (Baali 1988).

Consequently, asabiyyah is essential in the development of a civilized life, and in creating a structured system of government. Asabiyyah helps creating the existence of leaders and people under their leadership. According to Ibn Khaldun, asabiyyah or sense of belonging among a group of people towards their leader will give power to a government (Ibn Khaldun 2000). Group feeling and sense of belonging can create the sense of obedience among the people under his leadership. Sense of belonging is based upon the fundamental beliefs of religion and faith (Ibn Khaldun 2000).

Needless to say, asabiyyah or group solidarity normally grows among people of the same group, race, language and culture. It motivates people to form a group that will eventually emerge as nationalities (Gierer 2001). Asabiyyah is strong in the nomadic phase of human civilization and decreases as civilization advances. The final goal of social solidarity or asabiyyah according to lbn Khaldun is sovereignty.

Meanwhile, Ibn Khaldun also asserted that Allah the Almighty has given the responsibility to man as His vicegerent on earth. As inheritors of the Prophets, leaders are tied directly to fulfill the obligations towards Allah the Almighty and carrying out the task to govern the people (Ibn Khaldun 2000). In this case, a leader must exercise the law of God, perform kindness al-amr bi al-ma'ruf wa al-nahy an al-mungkar and to respect the religious clerics. Ibn Khaldun stressed that a leader is 
entitled to loyalty and support of the people when he has a sense of respect for the scholars, the righteous, those who are respected among the family of the Prophet, the rank, the traders and foreigners, and he must be able to practice justice (Ibn Khaldun 2000). Ibn Khaldun wrote:

"Therefore, today, the scholar in this field needs to know the principles of politics, the (true) nature of existent things, and the differences among nations, places, and periods with regard to ways of life, character qualities, customs, sects, schools, and everything else... He must be aware of the differing origins and beginnings of (different) dynasties and religious groups, as well as of the reasons and incentives that brought them into being and the circumstances and history of the persons who supported them (Ibn Khaldun 1967, p. 55-56)."

Consequently, Ibn Khaldun considered that the growth of a human civilization does not occur through the growth of the city alone. In fact, it also requires good leadership to ensure social stability and peace. Hence, Ibn Khaldun asserted that the need for good governance and leadership in a society is a requirement. It is rather impossible to achieve a successful life among a society without the existence of good governance which upholds a prosperous civilization (Ibn Khaldun 2000). Concurrently, Ibn Khaldun indicated that delegation of authority is rational and necessary because no individual is capable of executing all matters alone (Ibn Khaldun 2000). Therefore, leaders usually need assistance from his ministers in carrying out administrative affairs.

In the meantime, Ibn Khaldun (2000) asserted that khilafah (leadership) are the successors of the Prophet who are responsible in preserving the religious as well as prosperous life of the society under his reign. Therefore, good governance and leadership in the Islamic perspective always encourage leaders to practice the value of faith, integrity, self-discipline, self-restraint, loving, kind and generous. Besides, leaders are also encouraged to refrain from sinful acts and live life in moderation. Thus, the Allah-fearing attribute in a person will ensure that he perform his duty with trustworthiness (amanah), devotion and perfection. Similarly al-Ghazali (1058-1111 A.D.) in his political thought also affirmed that state and religion are inseparable as he argued that it is necessary for a state to possess a supreme spiritual leader, or otherwise turmoil (fitnah) will prevail. Al-Ghazali had also stipulated qualities for a good leader such as piety, knowledgeable and has the capability to rule (Yola 2011).

In his theory of good governance, Ibn Khaldun had also listed three types of ruling government model which consist of first siyasah tabiiyyah (government based on natural rule) refers to a ruling government that governs the country with his own desires, wills and lust. Secondly is siyasah 'aqliyyah (government based on reason) which refers to a government that is based on rational and man-made laws. Thirdly is siyasah diniyyah (government based on religion) where laws are derived from religious teachings (Ibn Khaldun 2000). Notwithstanding to the above facts, in performing his duties, a leader with strong faith will be stimulated by the great reward from Allah the Almighty more than the worldly or other materialistic goal.

Good governance is further believed to be free from corruption and social injustice (Alam 2008). Hence, Ibn Khaldun believed that in carrying out a just rule, a leader need to have commendable qualities that can lead to loyalty, obedience and a sense of respect from the people toward his ruling government. Determined to have a praiseworthy qualities is a sign of a great leader (Ibn Khaldun 
2000). Among the merit listed by Ibn Khaldun is feeling humble when dealing with people and respect their feelings. According to Ibn Khaldun, a leader should not despise the people under his rule. That attitude will make people protest against his leadership (Ibn Khaldun 2000, p. 108-109). However, leaders must be wise to impose a strict rule in order to instill attuned people and govern effectively to ensure a progressive and successful society (Ibn Khaldun 2000).

Accordingly, Ibn Khaldun believed that an exemplary leader is the most convenient for the people under his rule. This is due to the fact that the public generally tend to imitate and follow their revered leader. That is the case as people generally view the leader as someone who possesses values of an ideal figure with much perfection. This can be compared as how the children see and imitate the behavior of their parents and the students imitate their teachers (Ibn Khaldun 2000).

Ibn Khaldun (2000) had categorized five stages of the development of a ruling government. First is the phase of construction. At this stage, the feeling of group solidarity helps the people to choose leader and giving him authority to rule. Second is the phase of consolidation whereby the leader tries to recruit followers to strengthen his leadership. Third is the prosperous stage when the ruling power enjoyed sovereignty and the people live in harmony. Fourth is the stage of contentment where people enjoy peaceful and prosperous life. Fifth is a stage of decay which occurred when the ruling power started to involve in tyranny, greed and wastage, satisfying his lust and pleasure. This is a period when a country heading towards its destruction. After the decay of the government, a new civilization will emerge and so the stages will be repeatedly experienced by the new government. This is known as cyclic theory as prescribed by Ibn Khaldun in his Muqaddimah.

As a matter of fact, Ibn Khaldun was the first to systematically analyze the function of economy and the role of government to its stabilization and to increase its output and employment. Ibn Khaldun viewed that the government has to play significant role to establish law and order conducive for economic activities. Good governance must focus on enforcement of property rights, protection of trade routes and security in order to ensure peaceful and harmonious trade relations and production. Likewise, government needs to enforce a minimum amount of surplus through taxation in order to provide appropriate services and necessary public works (Mujahidin 2018). Ibn Khaldun asserted that good governance is the one that has minimum bureaucracy, minimum mercenary armies to keep law and order, and minimum taxation on its citizens to finance the activities of the state administration. Likewise, Egbetunde \& Adedimeji (2016) believed that the actualization of good governance will reduce and eliminate tribal strives and communal confrontations in the society.

Ibn Khaldun noted a clear connection between property rights and justice. Similarly, al-Ghazali also affirmed that economic progress will be achieved if there is justice, peace, prosperity, and stability (Irijanto, Zaidi, Ismail, \& Arshad 2015). Injustice acts such as collecting unjustified taxes, infringe upon property rights, taking property by force and so forth can ruin a civilization. In addition, Ibn Khaldun highlighted the facts that civilization and its well-being as well business prosperity depend on productivity and people's efforts to do their best and gaining profits. Nevertheless, when people no longer do business in order to make a living and they cease all gainful activity, the business of a civilization starts to slump and deteriorate. Hence, as mentioned by Egbetunde \& Adedimeji (2016), implementing good governance and working towards the attainment of economic prosperity are the glaring attributes of Islamic teaching. With regard to this matter, al-Ghazali had also pointed out that the goal of social welfare concept is actually to preserve beneficiary lies in the protection of 
INTERNATIONAL JOURNAL OF ACADEMIC RESEARCH IN BUSINESS AND SOCIAL SCIENCES

Vol. 8, No. 9, Sept. 2018, E-ISSN: 2222-6990 @ 2018 HRMARS

the religion of Islam as al-din, as well as the soul (nafs), intellect (aql), descendant (nasl) and property (mal) (Zarqa 1980).

\section{Characteristic of a Good Leader as Basis for Good Governance}

The concept of good governance and leadership are intertwined. Hence good governance has apparently become a key standard which display a nation's credibility and performance (Joseph et al. 2016). Ibn Khaldun viewed that the concept of leadership derived from the feeling of group solidarity (asabiyyah). This group bonding among people in a community helps in the appointment of a leader to lead the group. As such, Ibn Khaldun highlighted some characteristic of a good leader. Among the relevant characteristics of a good leader described by Ibn Khaldun comprised of self-knowledge, high prudence, willing to carry out responsibility and execute punishment fairly and have perfect body and senses without any defects that can affect his judgments and actions (Ibn Khaldun 2000). In addition, leaders need to implement religious as well as worldly affairs.

Furthermore, as a prerequisite, a leader must possess knowledge related to governance. Without the knowledge of politics and administrations a leader will not be able to implement the rule smoothly, especially in considering matters related to the state administration. It is important for a leader to have the ability to make decisions as Ibn Khaldun referred to such leader as a mujtahid. With extensive knowledge and experience, a leader will be able to make ijtihad (religious decisions) and to avoid blind taklid (follow blindly) of his advisors' opinion (Ibn Khaldun 2000). In fact, a leader is responsible for appointing assistants who are really capable in helping him to implement the state administration.

Moreover, Ibn Khaldun also observed that a praiseworthy character will reflect the transparency of government leaders. Among other good characteristics of a leader listed by Ibn Khaldun includes attributes such as love to do good, highly prudent, generous, tolerant of the weak, respect for the guests, like helping those in need and the poor, patient in facing trials, faithful in performing duty, honour religious scholars and uphold religious tenets, execute God's commandments vigilantly, respect older people and teachers, being humble to the poor, willing to listen to grievances of those who need help and to keep themselves from committing fraud, cunning, and neglect of responsibilities (Ibn Khaldun 2000).

Those characteristics are specified in accordance with Ibn Khaldun's emphasis on the spirit of respect or sense of belonging (asabiyyah). Thus, when a leader has a sense of belonging, he will feel that the people under his ruling power as part of his own family. As such, he will always be sincerely willing to serve and sacrifice for the betterment and defense of the fate of his people (Ibn Khaldun 2000).

Ibn Khaldun also affirmed that a leader acts as a representative of Allah (khalifah) on earth and thus must implement and fulfill the responsibility of managing all that is under his rule with trust and empathy (Ibn Khaldun 2000). In this case, a leader need to have a very close and committed relationship with Allah the Almighty as well as maintain good relationship with other human beings (hablumminallah wa hablumminnannas). In other words, a leader must always maintain good relations with his people. He should take care of the development of the physical and spiritual needs of the people under his rule. Such a leader will win the support and loyalty from his people. 
On the other hands, in the lights of Islamic teachings, it is the responsibility of a leader to spread Islam and upholds its message and teachings (Ibn Khaldun 2000). In this case, missionary activities need to be implemented in order to raise the spirit of religion in a society so that everyone will adhere to the truth (Ibn Khaldun 2000).

Meanwhile, Ibn Khaldun also emphasized the values of simplicity that should be inculcated in every member of the governments. Ibn Khaldun mentioned that luxury and tyranny attitude may invite excessive damage and deterioration to a country. Luxurious attitudes often cause people to neglect religious duties, immersed in pleasures of the world and forget about the Hereafter. Consequently, the heart will be filled with bad characters. The community will become lazy to work and unwilling to strive for excellence. Gradually, the situation would cause a civilization to deteriorate and eventually collapse (Ibn Khaldun 2000)

Ibn Khaldun also highlighted that sedentary people including the ruling powers are concerned with all sorts of pleasures such as life luxury, occupation and worldly desires. Due to these kinds of pleasures, their souls will be inflicted with bad qualities, which will eventually cause them to lose their self-restrain or self-control over lustful matters (Soofi 1995).

The situation is rather different compared to the Bedouins life as they are only concerned with the needs and the necessities of life. Being not exposed to the luxurious life, their self-restrain or selfcontrol over lustful matters is well maintained. Furthermore, they are tightly bound to follow the traditional customs of the Bedouin life. Interestingly, this fact is perceived by Ibn Khaldun to relate with his theory of civilization decay. He asserted:

"It will later on become clear that sedentary life constitutes the last stage of civilization and the point where it begins to decay. It also constitutes the last stage of evil and of remoteness from goodness. It has thus become clear that Bedouins are closer to being good than sedentary people" (Ibn Khaldun 1967).

In addition, Ibn Khaldun viewed that a leader must respect the rivals (Ibn Khaldun 2000). He should be respectful and not defamed or vilify others weaknesses. He must also have respect for the neighbouring countries and recognize their achievements. Good character as shown by a great leader will enhance his position in the world. However, firm and courageous attitude should always inspire a leader to protect his people and maintain good administration on his territorial jurisdiction (Ibn Khaldun 2000).

According to Ibn Khaldun's thought, a leader should not be too choosy. This is due to the fact that the curmudgeonly attitude can lead to extreme actions towards the wrong people when those people have been forced to perform an action that is beyond their capabilities. As a result, Ibn Khaldun classified this fussy attitude as the weakness personality of a leader (Ibn Khaldun 2000). Hence, a leader must always be modest in all his actions based on the suitability of time and place.

Based on Ibn Khaldun's perspective, a wise leader should also be able to unite his people from all walks of life. This can help maintaining stability and prevent the rise of the insurgency, unrest or bloodshed (Ibn Khaldun 2000). This is due to the fact that rigor and extreme violence will only invite disaster and harms towards the government (Ibn Khaldun 2000). When the government uses the veto power, people will start to protest and no longer support the ruling government. 
According to Ibn Khaldun, the leader is also responsible to ensure that the people under his rule behave and adhere to the social norms as well as acts in accordance with the teachings of religion. This is noteworthy to ascertain success in life as well as in the Hereafter (Ibn Khaldun 2000). Hence, Allah the Almighty has appointed a leader as the caliph (the representative of Allah) on earth to perform his responsibility in managing the affairs of the people under his rule as well as to enjoin good and prevent shameful and wrong acts (Ibn Khaldun 2000).

However, Ibn Khaldun stressed that this power will disappear when there is abuse of power as a result of luxurious life and tyranny (Ibn Khaldun 2000). When powers begin to be misused, and leaders are immersed in luxury, negligence and ignore religious rules, in the end a civilization will surely experience its collapse. Those were the situations witnessed by Ibn Khaldun during his involvement in politics and administration, that he had written down in his Muqaddimah for the others to take heed and be mindful not to repeat the same mistake.

\section{Conclusion}

In conclusion, Ibn Khaldun was undoubtedly a prominent Muslim scholar in the study of Islamic history and civilization, famous for his unique magnum opus, al-Muqaddimah. The Muqaddimah is principally meant to be an introduction to the voluminous text of Kitab al-lbar which consists of Maghreb history. Yet, the creation of al-Muqaddimah seems to include other information pertaining to the study of human society, which comprises of information on good governance as well as characteristics of good leaders.

Indeed, browsing the writings of Ibn Khaldun in his Muqaddimah will give a chance for the readers to emulate lots of lessons from previous nations' experiences. Ibn Khaldun's explanations of the elements of good governance and characteristics of good leaders are very significant and relevant to be taken into consideration and applied in all circumstances and time.

Concisely, Ibn Khadun asserted that the concept of good governance and great leaderships are intertwined. Therefore, in his theory of good governance, Ibn Khaldun strongly believed that leaders uphold significant roles as successors of the Prophets. Hence they are responsible to ensure that the Laws of Allah are fully observed in all aspects of life. Meanwhile Ibn Khaldun also affirmed that group solidarity and sense of belonging will give power to a ruler and can create a sense of obedience among the people.

In the meantime, Ibn Khaldun also highlighted that great leaders must have praiseworthy qualities so that their leaderships is free from corruption and social injustice. In addition, Ibn Khaldun viewed that the government has to play significant role in establishing law and order conducive for economic activities. Hence, Ibn Khaldun suggested that a wise leader should also be able to unite his people from all walks of life. This can help maintaining stability and prevent the rise of the insurgency, unrest or bloodshed.

Simultaneously, Ibn Khaldun had also warned that if powers have been misused, and leaders were immersed in luxury, negligence and ignoring religious rules, the civilization will slowly experience phases of decline and collapse. With regard to this matter, it is obvious that good governance and leaders with good characteristics are like two sides of the same coin. Without leaders with good characteristics, people may not envisage good governance in its totality. 
Undoubtedly, Islamic principles of good governance and administration can bring massive impact towards the betterment of a society, nation and civilization. Hence, Ibn Khaldun urged that leaders are required to be committed to their responsibilities and at the same time willing to accept changes, encourage exploration of knowledge, executing justice in administration as Allah's vicegerents on earth (khalifah), maintaining stability and ensuring high appreciation of religious teachings for himself as well as among his people. Notwithstanding the facts that Ibn Khaldun has written his Muqaddimah hundreds of years ago, nevertheless the ideas expressed in his book are still relevant until our present time.

On the final note, it can be concluded that leaders, particularly among the Muslims should take lessons from the exemplary leadership portrayed by Prophet Muhammad p.b.u.h. as well as His Companions, as suggested by Ibn Khaldun. Similarly, examples can also be infused from the experiences of the Islamic governments in the past as described by Ibn Khaldun in al-Muqaddimah. This is due to the fact that history is often repeated when people do not want to learn from past experience.

\section{Corresponding Author}

Suhaila Abdullah, Ph.D

School of Humanities, Universiti Sains Malaysia

11800 Penang, Malaysia

Email: aila@usm.my

\section{References}

Agere, S. (2000). Promoting good governance: Principles, practices and perspectives. London: Commomwealth secretariat.

Al-Ahsan, A. \& Young, Stephen B. (eds.) (2017). Qur'anic guidance for good governance: A contemporary perspective. Switzerland: Palgrave Macmillan.

Alam, G. M. (2008). Impact of private higher education on Bangladeshi education system: An investigation of education policy. Germany: VDM Verlag. 5 (2). 100- 113.

Zarqa, A. M. (1980). Islamic economics: An approach to human welfare. In Khurshid Ahmad (ed.). Studies in Islamic economics. Leicester: The Islamic foundation.

Baali, F. (1988). Society, state and urbanism: Ibn Khaldun's sociological thought. Albany: State University of New York Press.

Bates, R. H. (2001). Prosperity and violence: The political economy of development. New York: W. W. Norton. 
INTERNATIONAL JOURNAL OF ACADEMIC RESEARCH IN BUSINESS AND SOCIAL SCIENCES Vol. 8, No. 9, Sept. 2018, E-ISSN: 2222-6990 (C) 2018 HRMARS

Blunt, P. (1995). Cultural relativism, 'good' governance and sustainable human development. Public administration and development. Vol. 15. Issue 1. https://doi.org/10.1002/pad.4230150102 (retrieve date: 19.8.2018)

Campo, J. E. (2009). Ibn Khaldun, Abd al-Rahman ibn Muhammad. In Campo, Juan E. (ed.). Encyclopedia of Islam. New York: Facts of File. 334-335.

Darwin, C. (1981). The descent of man, and selection in relation to sex. Princeton, New Jersey: Princeton University Press.

Egbetunde, T. \& Adedimeji, A. A. (2016). Good governance and economic prosperity in Sub-Saharan Africa: The Islamic perspective. Journal of management and social sciences. 5 (2) 63-79.

Enan, M. A. (1979). Ibn Khaldun: His life and works. New Delhi: Kitab Bhavan.

Freud, S. (2005). Civilization and its discontents. James Strachey (tr. and ed.). New York: W.W. Norton \& Company Inc.

Gierer, A. (2001). Ibn Khaldun on solidarity ("asabiyyah") - modern science on cooperativeness and empathy: A comparison. In Philosophia naturalis. Germany: Vittorio Klostermann. 38 (1), 91-104.

Ibn Khaldun, A. (2000). Muqaddimah Ibn Khaldun. Beirut: Dar al-Kutub al-'Ilmiyyah.

Ivancevich, J. M., Konopaske, R. \& Matteson, M. T. (2008). Organisational behaviour and management. Eighth Edition. New York: McGraw-Hill International Edition.

Joseph, K. O., David, I. \& Kikelomo, E. I. (2016). Good governance and leadership: Pathway to sustainable national development in Nigeria. Journal of public administration and governance. Vol. 6. No. 1. 35-49. https://doi.org/10.5296/ipag.v6i1.9055

Kant, I. (1963). Conjectural beginning of human history. In On history. New York: Macmillan.

Khan, M. H. (2007). Governance, economic growth and development since the 1960s. In Ocampo, Jose Antonio, K. S. Jomo and Rob Vos (eds). Growth divergences: Explaining differences in economic performance. Hyderabad, London and Penang: Orient Longman, Zed Books and Third World Network. Retrieve from http://www.un.org/esa/desa/papers/2007/wp54 2007.pdf

Leakey, R. (1995). The origin of humankind. New York: BasicBooks.

Mohamed, M. (1998). State of governance. Public administration and development. Vol. 18. No. 5. John Wiley \& Sons, Ltd. 441-446. https://doi.org/10.1002/(SICI)1099-162X(199812)18:5<441::AIDPAD42>3.0.CO;2-S 
INTERNATIONAL JOURNAL OF ACADEMIC RESEARCH IN BUSINESS AND SOCIAL SCIENCES Vol. 8, No. 9, Sept. 2018, E-ISSN: 2222-6990 (C) 2018 HRMARS

Maldonado, N. (2010). The World Bank's evolving concept of good governance and its impact on human rights. Doctoral workshop on development and international organizations. Stockholm, Sweden. May 29-30, 2010.

Mohammad, M. T. S. (2010). Principles of sustainable development in Ibn Khaldun's economic thought. Malaysian journal of real estate. Vol. 5. No. 1. 1-18.

Mujahidin, M. (2018). The concept of economic thought Ibn Khaldun. Munich Personal RePec Archive (MPRA) Retrieve https://mpra.ub.uni-muenchen.de/87143/1/MPRA_paper_87143.pdf

North, D. C. (1990). Institutions, institutional change and economic performance. Cambridge: Cambridge University Press.

Olson, M. (2000). Dictatorship, democracy and development. In Olson, Mancur and Satu Kahkonen (eds). A not-so-dismal science: A broader view of economies and societies. Oxford: Oxford University Press.

Smith, B. C. (2007). Good governance and development. New York: Palgrave Macmillan.

Soofi, A. S. (1995). Economics of Ibn Khaldun revisited. In History of political economy. Duke University Press. 27 (2) 387-404. doi: 10.1215/00182702-27-2-387.

UN system task team on the post-2015 UN development agenda (2012). Governance and development- Thematic think piece. UNDESA, UNDP and UNESCO.

Wagener, H. (2004). Good governance, welfare, and transformation. The European journal of comparative economic. Vol. 1. N.1. 127-143. Retrieve from http://eaces.liuc.it

World Bank (1992). Governance and Development. Washington: The World Bank.

Yola, J. H. (2011). The political view of Imam al-Ghazali. In Ismail A. A. \& Shehu, S. (eds.) Islamic political thought and institutions. Kano: International Institute of Islamic Thought. 